\title{
Trainees and covid-19: your questions answered
}

\author{
Abi Rimmer
}

The BMJ

\section{Will my training be disrupted?}

In a joint statement, UK training bodies and the General Medical Council have said that there will be increased requirements for trainees and trainers to support the management of acutely unwell patients. " "This might result in disruption or cancellation of training activities and trainees being directed to alternative tasks and/or locations to support the covid-19 response," it said. "This could mean trainees in non-acute areas being asked to support urgent and unplanned care, such as medical admissions and the subsequent management of those patients, but may also in exceptional circumstances include providing support to clinical teams in other disciplines."

\section{What if I fail to meet my training requirements due to the disruption?}

The training bodies have recognised that this might happen. Their statement says that "the statutory education bodies together with the GMC and AoMRC [Academy of Medical Royal Colleges] are determined to ensure the longer term needs of doctors in training are not compromised."

\section{Will my exams be cancelled?}

So far, some royal colleges have taken the decision to cancel their exams.

The Royal College of Physicians (RCP) announced on 12 March that six MRCP (UK) PACES exams had been cancelled due to growing concerns about the continuing outbreak of covid- 19 . These exams were due to take place in Dudley, UK, as well as overseas. ${ }^{2}$ The RCP said, "We would like to apologise for any inconvenience this might cause, but the safety and security of our candidates, patients, hosts, and examiners are of paramount importance when reaching important decisions such as this."

The Royal College of Radiologists has cancelled some exams that were scheduled to take place in Singapore and Hong Kong. ${ }^{3}$ The college said that it hoped to continue with all exams in the UK, but this decision will be under constant review.

On 11 March, the Royal College of Psychiatrists confirmed that it still intended to run the Paper B written exam in the UK, Ireland, and Chennai. ${ }^{4}$ It said that the situation was being monitored regularly and that candidates would be notified by email if anything changed. The college has cancelled exams in Hong Kong, Singapore, Oman, and Malta. ${ }^{5}$

In a joint policy statement published on 13 March the royal surgical colleges announced that from Monday 16 March, conferences, educational and training courses, assessment panels, accreditation visits, and examinations that require travel will be postponed. "Where this involves the postponement or cancellation of events and examinations already paid for, participants will be booked onto the next available slot, once activities resume," the statement said. ${ }^{6}$

The Royal College of Pathologists has deferred all its Spring examinations. It said in a statement, "The examinations will be rescheduled later in the year. We will stay in touch with candidates and examiners regarding dates and arrangements."

Other colleges have decided not to cancel their exams for the time being. The Royal College of Anaesthetists said, "At present we have not cancelled any UK based events or activities in keeping with government advice, and we continue to review this on a daily basis."

\section{Will my specialty training interview go ahead?}

Health Education England issued guidance on 12 March, which said that the recruitment and selection timetable remained unchanged and that the schedule of selection centres was being planned as normal. "We are reviewing the situation carefully and will communicate any changes to the timetable and process with updates on the specialty training website and Oriel," the statement said."

\section{I have been forced to turn down a specialty training interview due to self-isolation. What happens to my application?}

Health Education England's guidance said that applicants travelling or recently returned from the specified countries that are deemed high risk should not attend selection centres and instead contact the lead recruiter for alternative arrangements. It also said that applicants travelling from or who have returned from category 1 specified countries or areas in the past 14 days should self-isolate. This includes avoiding attending a selection centre until 14 days after they return.

"Applicants who have returned from category 2 specified countries/areas in the past 14 days are advised to stay at home if they develop symptoms," the statement said. Applicants who have come into contact with someone with corvid-19 or are experiencing symptoms and are self-isolating for a 14 day period that covers the scheduled interview date should also contact the 
lead recruiter regarding their interview, Health Education England said. ${ }^{9}$

\section{Guidance principles for all trainees (from the UK training bodies) ${ }^{1}$}

Trainees must not be asked to undertake any activity beyond their level of competence and must be advised that they should seek senior workplace guidance if that arises

The relevant postgraduate dean should be informed of plans to redeploy trainees of any grade

Trainees deployed to a different clinical area must have appropriate induction and be informed of who they are reporting to and who is providing supervision, with details of how to contact them

Arrangements for redeployed trainees should be reviewed weekly and updates provided to the relevant postgraduate dean on a weekly basis to ensure that trainees are adequately supervised in the host environment or specialty and that they continue to work within the limits of their competence appropriate to their stage of training

Where training is interrupted or learning outcomes are not achieved due to a major incident response, these issues will be taken into account at the trainee's next annual review of competence progression, which will inform future training requirements and placement planning

Current recruitment and selection processes are continuing, and guidance for candidates will be updated regularly.

\section{Useful resources}

Academy Trainee Doctors' Group. Update for trainee doctors regarding covid-19 https://www.aomrc.org.uk/wp-content/ uploads/2020/03/200311_ATGD_COVID-19-update.pdf

Letter from four UK statutory education bodies. Supporting the covid-19 response: guidance regarding medical education and training https://www.nimdta.gov.uk/download/ supporting-the-covid-19-response/

Letter from four chief medical officers. Supporting doctors in the event of a covid-19 epidemic https://www.aomrc.org. uk/wp-content/uploads/2020/03/0320_letter_supporting _ doctors_in_COVID-19.pdf

Letter from Health Education England. Covid-19 and plans for management of medical and dental training programmes https://www.hee.nhs.uk/sites/default/files/documents/ COVID-19\%20letter\%20to\%20Trusts\%20and\%20GP\% 20Practices\%2010.03.2020.pdf
Health Education England. Pandemic and major infectious diseases management plan https://www.hee.nhs.uk/newsblogs-events/news/pandemic-major-infectious-diseasesmanagement-plan-procedure

Public Health England. Covid-19: infection prevention and control guidance https://www.gov.uk/government/ publications/wuhan-novel-coronavirus-infection-preventionand-control/wuhan-novel-coronavirus-wn-cov-infectionprevention-and-control-guidance

Public Health England. Guidance for healthcare providers: healthcare workers with relevant travel, healthcare or household contact history https://www.gov.uk/government/ publications/novel-coronavirus-2019-ncov-guidance-forhealthcare-providers-with-staff-who-have-travelled-to-china/ guidance-for-healthcare-providers-healthcare-workers-whohave-travelled-to-china

Health Protection Scotland. Information for Scotland regarding covid-19 https://www.hps.scot.nhs.uk/a-to-z-oftopics/wuhan-novel-coronavirus/

General Medical Council and joint regulators statement. How we will continue to regulate in light of novel coronavirus (covid-19) https://www.gmc-uk.org/news/newsarchive/how-we-will-continue-to-regulate-in-light-of-novelcoronavirus

BMA. Coronavirus disease 2019 (covid-19) https://beta.bma. org.uk/what-we-do/population-health/drivers-of-ill-health/ coronavirus-disease-2019-covid-19?imgdoctors=

1 Health Education England, NHS Education for Scotland, Health Education and Improvement Wales, Northern Ireland Medical and Dental Training Agency. Supporting the covid-19 response. $10 \mathrm{Mar}$ 2020. https://www.nimdta.gov.uk/download/supportingthe-covid-19-response/

2 Membership of the Royal Colleges of Physicians of the United Kingdom. Exam cancellations due to covid-19. https://www.mrcpuk.org/news/exam-cancellations-duecovid-19

3 Royal College of Radiologists. RCR position on coronavirus (covid-19) and April/May/June RCR exams. https://www.rcr.ac.uk/college/coronavirus-covid-19-what-rcr-doing/rcr-positioncoronavirus-covid-19-and-aprilmayjune-rcr

4 Royal College of Psychiatrists. Updates on MRCPsych examinations-covid-19 (coronavirus). 11 Mar 2020. https://www.rcpsych.ac.uk/news-and-features/latest-news/ detail/2020/03/11/coronavirus-covid-19-updates-on-mrcpsych-examinations

5 Royal College of Psychiatrists. Exam cancellations in Hong Kong, Singapore, Oman, and Malta (coronavirus). https://www.rcpsych.ac.uk/training/exams/exam-cancellations-hongkong-singapore

6 Joint policy statement from the Royal Surgical Colleges. 13 Mar 2020. https://www.bssh. ac.uk/_userfiles/pages/files/Joint\%20Policy\%20Statement\%20on\%20COVID-19.pdf

7 Royal College of Pathologists. Royal College of Pathologists takes hard decision to defer examinations. 13 Mar 2020.https://www.rcpath.org/discover-pathology/news/royal-collegeof-pathologists-takes-hard-decision-to-defer-examinations.html

8 Royal College of Anaethetists. Covid-19: RCoA's preparations. 7 Mar 2020. https://www. rcoa.ac.uk/news/covid-19-rcoas-preparations

9 Health Education England. Coronavirus (covid-19)—specialty recruitment guidance. 12 Mar 2020. https://specialtytraining.hee.nhs.uk/Coronavirus-COVID-19

Published by the BMJ Publishing Group Limited. For permission to use (where not already granted under a licence) please go to http://group.bmj.com/group/rights-licensing/ permissions 